\title{
The Psychological Healthand Social Impacts of Constitutional Court's Verdict No. 97/PUU-XIV/2016
}

\author{
Nanik Prasetyoningsih ${ }^{1}$, Muchammad Ichsan $^{1}$ \\ ${ }^{1}$ Lecturer, Faculty of Law, Universitas Muhammadiyah Yogyakarta
}

\begin{abstract}
After the Constitutional Court's Verdict No. 97/PUU-XIV/2016, acolytes of beliefs have electronic identification cards and family cards which say, "Belief towards the Almighty God" in the "religion" column. In this case, the status of the acolyte of beliefs' existence is more acknowledged administratively in Indonesia. The research method used in this study is the normative-empirical 1 research method. The data is collected using the literature study and interview methods. The aim of this research is to know how the psychological and social impacts of the Constitutional Court's verdict are. This research finds that the acknowledgement of this status gives psychological and social impacts towards the life of the acolytes. The psychological and social impacts of the Constitutional Court's Verdict happened to the uncertainty and doubt of the acolytes. If they change their statuses, they will face many problems and they must leave the comfort zone they have stayed at for so long. This research has value as the "religion column" is sensitive and results to impacts in Indonesia.
\end{abstract}

Keywords: Constitutional court, acolyte of beliefs, juridical, social, impacts.

\section{Introduction}

The Constitutional Court's Verdict No. 97/PUU$\mathrm{XIV} / 2016$ regarding the examination of the Constitution No. 23 of 2006 regarding the Citizenship Administration, as what is changed with the Constitution No. 24 of 2013 regarding the change of the Constitution No. 23 of 2996 regarding the Citizenship Administration regarding the Republic of Indonesia's 1945 Constitution states that the stipulations of Article 61 clause (1) and clause (2), also Article 64 clause (1) and clause (5) regarding the void of the "religion" column in Family Card and the electronic Identification Card which is against the constitution. ${ }^{(1)}$ The consequence of the Constitutional Court's Verdict is that the acolytes of traditional beliefs can now publish their beliefs in the "religion" column both in the Family Card and the electronic Identification Card. The basis of the Constitutional Court's Verdict is that the rights to

\section{Corresponding Author:}

Nanik Prasetyoningsih

Universitas Muhammadiyah Yogyakarta

e-mail: nprasetyoningsih@gmail.com become a follower of a religion or a belief towards the Almighty God is a constitutional right of the citizens. The basis of the state's responsibility to protect all streams of beliefs in Indonesia is the stipulations of Article 28I clause (4) which states that, "The protection, development, enforcement, and fulfillment of the human rights is the responsibility of the state, especially the government."(2)

With the understanding which is constructed using lexical interpretations, the Constitutional Court uses it as the initial basis in understanding the position and the relations between "religion" and "belief" as stated in Article 28E clause (1) and clause (2) and Article 29 of the Republic of Indonesia's 1945 Constitution. Then, to affirm the interpretation above, the Constitutional Court reviewed those articles' formulation history. The Constitutional Court then concludes that based on the formation process of Article 29, Article 28E clause (1) and clause (2) of the Republic of Indonesia's 1945 Constitution, "religion" and "belief" are regarded as separate things, as the two are regulated in two different clauses. It's just that, by regulating "religion" and "belief" in two different norms, it can be said that the 
Republic of Indonesia's 1945 Constitution basically regards "belief" as different from "religion". (3) Because of this, on one side, "religion" and "belief" are regarded as separate things, as they are regulated in Article 28E clause (1) and Article 28E clause (2). But, on the other side, "belief" is also understood as part of the religion as stated in Article 29 of the Republic of Indonesia's 1945 Constitution. Further, the term "religion" in Article 61 clause (1) and Article 64 clause (1) should be defined as part of "belief" so that it is according to the norms in Article 1 clause (3) of the Republic of Indonesia's 1945 Constitution. Legally, it is very reasonable, so that the two articles do not contradict one another with the principles of law certainty and non-discrimination (same treatment in the face of law) as guaranteed in Article 28D clause (1) in the Republic of Indonesia's 1945 Constitution. It also violates the citizens' guarantee of equality in the face of law as stipulated in Article 27 clause (1) of the Republic of Indonesia's 1945 Constitution.

\section{Method}

The research method used in this study is the normative-empirical legal research method. The data is collected using the literature study and interview methods. This is a qualitative research. The analysis is carried out towards the data from the introductory study results or secondary data. The analysis of the qualitative data in the field was carried out using the Miles and Huberman analysis models ${ }^{(4)}$, which include data reduction, data model, verification or conclusion. In this qualitative research, the data analysis was carried out simultaneously with the data collection process.

The data analysis used is the descriptive-qualitative and explanative analyses. The research results are described in narratively, which explains and describes the objects analyzed.

\section{Discussion}

Psychological Impact: Interpretation of the streams of belief outside of the government-acknowledged official religions which are Hinduism, Buddhism, Islam, Christianity, Catholic, and Kong $\mathrm{Hu} \mathrm{Chu}$; or the formal legality of the various belief streams which exist in Indonesia, is an Indonesian cultural heritage which are spiritual and mystical ${ }^{(5)}$. The law which regulates the survival rights of the belief streams are defined as the freedom which is still in the boundaries of tolerance. It is so that there is harmony in the life of people in practicing their religions and beliefs. Plus, in carrying out their activities, the followers must comply with the constitutional regulations which apply, so that there is no emergence of social and legal issues.

There is the impression of ambiguity and contradiction between the regulative conceptions regarding the protection, respect, and fulfillment of the rights of religious and belief freedom in Indonesia; remembering that on one side, the state formulates a regulation which gives an affirmation that the rights for the freedom of beliefs and religion are non-derogable rights which cannot be decreased in any condition. There must not be discrimination, and the state has the responsibility in respecting, fulfilling, and protecting it. But, on the other side, the state also stipulates regulations which limit, decrease, and revoke the rights for the freedom of religion and beliefs. The dimension of the human rights legal regulations is on one hand universal and non-discriminatory. But, on the other hand, the dimension of the human rights law conception is particular and discriminative. ${ }^{(6)}$

The existence of the stream of belief acolytes in Indonesia has been legally and formally regulated in some constitutional regulations. Some of these regulations actually indicate two things, which are: (1) the formal existence, as mentioned in Pancasila, the Republic of Indonesia's 1945 Constitution Articles 28E, 29, and 32, the Constitution No. 23 of 2006 regarding Citizenship Administration, and the Governmental Decree No. 37 of 2007 regarding the Implementation of the Constitution No. 23 of 2006 regarding Administration, and (2) the existence of the belief acolytes, especially regarding the history and the individual awareness of each acolyte.

According to the Director of the Belief to the Almighty God and Tradition, General Director of Culture, the Ministry of Education and Culture, Sri Hartini, in Indonesia there are around 12 million acolytes and followers of beliefs which are spread in 26 provinces, with 187 central-level organizations and 1.034 branches. The coaching for the belief acolytes were carried out based on the Presidential Decree No. 27 of 1999. On the New Order Era, based on the Outline of the State's Direction (GBHN), the beliefs of the local religions are categorized into the stream of beliefs. At that time, the coaching of the stream of beliefs were directed so that they come back to the origin of each religion. At the New Era governmental period, a policy was issued which directs the local religions to join in the religion in which its teachings are similar to the mothering 
religion (the majority's religion). Some local religions such as Kaharingan (Dayak tribe, Borneo) and Aluk To Dolo (Tana Toraja tribe, Sulawesi) were merged into Hinduism. The Kong $\mathrm{Hu}$ Chu religion was merged into Buddhism. With the repressive governmental policies at that time, thus, to save the followers of the local religions, they were forced to join in the five religions which were approved by the government thus the feels psychological opressed. ${ }^{(7)}$

The formal existence of the belief stream followers towards the Almighty God has been formulated in the 1945 Constitution and the 1998 Outline of the State's Direction, even though there are still some fundamental deficiencies. The Constitution's mandate, as stated in Articles 28E and 29 has affirmed that the legal basis and the survival rights of the streams of beliefs in Indonesia gives a social reality aside from the existing religious institutions. Thus, the streams of belief obtain the human rights protection with the freedom to embrace a belief which is according to their conscience. They also have the freedom to create organizations. ${ }^{(5)}$

Social Impacts: Still questions whether or not the Belief towards the Almighty God is a religion. This doubt must be given clarity, so that there are no conflicts between the belief acolytes and other members of the society. According to Endang, a belief is a manner of believing in God. The belief acolytes are administratively acknowledged, as it is allowed for the acolytes to publish their beliefs in the "belief" column in the electronic Identification Card or Family Card. ${ }^{(8)}$ Yet, in its development, not all belief acolytes have changed the status in their electronic Identification Cards or Family Cards into the belief they have. This may be caused by the family, work, social environments, or others. There are some belief acolytes who are in a family environment which embraces a certain religion. Thus, to maintain the peace in the family, that acolyte have not proposed for the electronic Identification Card or Family Card status change. This is because from the start, that person had a religion. ${ }^{(9)}$

There are also some people who are raised in a family which acknowledges and embraces both religion and belief. The parents and the children both have two beliefs, which are as embracers of a religion and as acolytes of a belief. Usually, those people have electronic identification cards which state one of the valid and acknowledged religions in Indonesia. Thus, this type of people doesn't feel the need to propose to have their belief stated in the electronic Identification Card or Family Card as they are comfortable with the status quo. From the start, they already have both a belief and a religion.

The work environment factor may also become the obstacle of the belief acolytes to change their status, considering that the change of status may change the employment administration data. Usually, the acolytes who have the status as Civil State Employees have written one of the valid religions in the electronic Identification Card or Family Card.

In the case of citizenship administration, MLKI returns this to each individual. They may or may not change the status in the electronic Identification Card or Family Card.

According to Endang, even though the belief acolytes write one of the religions in the electronic Identification Card and Family Card, they are actually belief acolytes who are true followers. Usually, the faith of the belief acolytes is very strong. This means that the belief acolytes do not want to carry out the rituals or worshipping methods of other religions or beliefs. The case where an acolyte of an "A" belief converts to become the acolyte of a " $\mathrm{B}$ " belief very seldom happens. This is what actually makes the bond between the belief acolytes in a faith very strong. Thus, the belief acolytes are also reluctant to preach to acolytes of other beliefs to join their belief. The belief acolytes use the Javanese principle which is popular in Javanese language, which is, "timbo sing marani sumur duduk sumur marani timbo". It means that the belief acolytes do not preach. They only give examples from their actions. They are welcome to those who believe or those who want to follow. But the belief acolytes do not carry out a particular missionary endeavor. ${ }^{(10)}$

So, basically, the Belief towards the Almighty God is mostly as described. There is the principle that when someone is a follower of a particular belief, he/she should not show it nor should he/she act proud about it. But, if someone asks about it, they will answer the questions. In the Yogyakarta Special Province, there are Belief Associations which are open to public, such as SaptoDarmo.

Most beliefs in Indonesia do not have a Book of Teachings which are documented in the form of books, because there are some prohibitions from writing down or documenting the teachings. The teachings from the 
ancestors may only be memorized.(11) It is not allowed to be written down. The MLKI of Yogyakarta Special Province has suggested the Belief Associations to write down their teachings. But there are still associations which do not want to write them down, as they believethat the teachings cannot or may not be written down. This makes it difficult for the MLKI in the Yogyakarta Special Province to create the belief profiles.

Socially, the issuing of the electronic identification cards and family cards which include the belief has some advantages and disadvantages, according to Endang. The advantage is that the belief acolytes whose spirits are strongly attached to the belief will change their statuses. ${ }^{(12)}$ The minus is that there are those who doubt the need to. They worry that they may face problems if they change the status. This worry is usually caused by the social environment factor.

Actually, all governmental institutions are already very opened. They accept the participation of the belief acolytes in the government, and there are no more discriminations, so there's nothing to worry about. The acolytes are also accepted as members of the People's Representative Council of the Region, legislative candidates in the 2019 general election, and the Head of the Region candidate, like one of the Surabaya Mayor candidates who embraces SaptoDarmo. Thus, the General Election Commission has treated all candidates equally and without discrimination.

\section{Conclusion}

The Constitutional Court has pushed the government to issue some constitutional regulation instruments with the aim to give equal services and protection to the Belief Acolytes. The Belief Acolytes experience psychological and impacts in the aspects of citizenship, education, marriage, and institution of the Belief Acolytes. The inclusion of the belief in the electronic identification cards and family cards makes the Belief Acolytes more opened and aceepted by the society. They admit their belief in the society. The society also starts to believe that the Belief towards the Almighty God is a belief which must be respected. The impact in the psychological of acolytes is excellent.

\section{Conflict of Interest: No}

Source of Funding: Authors

Ethical Clearance: Yes.

\section{References}

1. Hafsin A. Democracy in Indonesia: Between the Limitation and Freedom of Religion. Analisa. 2010;17 (1):9-18, p 13.

2. Zainuddin M. The freedom of religion and democratization in Indonesia. El-Harakah. 2009;11(2):172-80, p.176.

3. Faiz PM. Constitutional review and the freedom of religion protection [online].2009. p. 202. Available at: Http://Panmohamadfaiz.Com.

4. Huberman MB, Michael MA. Qualitative data analysis, source book on the new methods. Jakarta: Penerbit Universitas Indonesia; 1992.

5. Nurdjana. The law and the deviating streams of belief in Indonesia. Yogyakarta: Pustaka Pelajar. p. 71.

6. Syafi'ie M. Ambiguity of the freedom of religion in Indonesia and its position post-decree of the constitutional court.Jurnal Konstitusi. 2011;8(5):701.

7. Ichsan M.and PrasetyoningsihN. The interpretation of 'streams of belief' in the constitutional court decree no. 97/PUU-XVI/2016: Analysis from the perspective of the Islamic law and the 1945 constitution. Yogyakarta. 2018.

8. Triyanta A. The search for the constitutional red thread between the freedom and the defilation of religion: from the concept of blasphemy law until the prohibition of Ahmadiyah in Indonesia. UNISIA2011;35(September):25-33, 27.

9. Krisdanar VDA. Initiating constitutional complaint in protection the people's constitutional rights on living and freedom of religion in Indonesia.Jurnal Konstitusi. 2010;7(3):186-208, 193-194.

10. Yusdani. The freedom of religion in the perspective of the human rights.Al-Mawarid. 2011;11(2): 272.

11. A Budiono, W Silalahi, AH Ngestiningrum, WV Izziyana. Visum Et Repertum in the Evidencing Process of Rape in Indonesia. Indian Journal of Forensic Medicine \& Toxicology. 2020;14(2):167171.

12. R Rizka, WV Izziyana, A Budiono, HSW Nugroho, SWA Pradnyawan. Visum Et Repertum and Forensic Examination of a Rape Case as a Sexual Crime Towards an Indonesian Migrant Worker in Taiwan. Indian Journal of Forensic Medicine \& Toxicology. 2020;14(2):2538-2542. 